\title{
Human Resource Diversity Management Practices and Organizational Citizenship Behavior: A Conceptual Model
}

\author{
Ahmad Nizan Mat Noor \\ Lecturer, Faculty of Business Management, Universiti Teknologi MARA, Perlis, Malaysia \\ Email: ahmadnizan@perlis.uitm.edu.my
}

\section{Dr. Shaiful Annuar Khalid}

Senior Lecturer, Faculty of Business Management, Universiti Teknologi MARA, Perlis, Malaysia

\section{Dr. Nik Ramli Nik Abdul Rashid}

Senior Lecturer, Faculty of Business Management, Universiti Teknologi MARA, Perlis, Malaysia

DOI: $\quad 10.6007 / I J A R B S S / v 3-i 8 / 144$

URL: http://dx.doi.org/10.6007/IJARBSS/v3-i8/144

\begin{abstract}
The purpose of this concept study is to unravel the relationship between Human Resource Diversity Management (HRDM) practices and Organizational Citizenship Behavior (OCBI and OCBO). This study also attempts to identify and classify available HRDM factors found to have significant relationship with OCB and identify HRDM factors that have not been explored in the OCB research, but have potentials in predicting employees OCB. This new classification is important in presenting a better insight into how HRDM practices relate to employees OCB as well as identifying research gaps regarding HRDM practices and OCB relationships.
\end{abstract}

Keywords

Human Resource Diversity Management Practices, Organizational Citizenship Behavior

Introduction

Over the decades, studies on organizational citizenship behavior (OCB) has become a phenomenon in organizational behavior research as it was discussed extensively in psychology and management fields and obtained much attention in the literature (Bateman \& Organ, 1983; Niehoff \& Moorman, 1993; Organ \& Ryan, 1995; Podsakoff, MacKenzie, Paine, \& Bachrach, 2000). The concept of OCB was first introduced by Bateman and Organ (1983), which relied on the notions of willingness to cooperate (Barnard, 1938) and spontaneous or extra-role behaviors (Katz, 1964; Katz \& Kahn, 1978). Since then, the development of OCB construct has been reported to receive vast interests from both practice and academia (Triana, Kim, \& Garcia, 2011). Originally defined, OCB is "individual behavior that is discretionary, not directly or explicitly recognized by the formal reward system and that in the aggregate promotes the 
effective functioning of the organization" (Organ, 1988, p. 4). In addition, Organ (1988) also noted that the word discretionary is the behavior that is not a requirement of a formal job description and is a matter of personnel choice, and failure to demonstrate such voluntary behavior is not commonly considered as a cause of punishment.

Empirically, researchers noted that $\mathrm{OCB}$ is essential and vital to organizational functioning (Bateman \& Organ, 1983; Organ, 1988) and also beneficial to organizations (Bolino \& Turnley, 2003). Organ (1988) pointed out that the survival of organization is heavily depending on OCB because it has potentially contributed in maximizing a range of organizational outcomes such as the coworker, managerial and team productivity and also organizational performance (Podsakoff, et al., 2000). Considering its important consequences to the organizations, most research have investigated various antecedents of OCB (e.g. Organ, Podsakoff, \& Mackenzie, 2006; Podsakoff, et al., 2000; Smith, Organ, \& Near, 1983). Hence, Podsakoff and associates (2000) classified OCB antecedents into four categories that are individual characteristics, task characteristics, organizational characteristics and leadership behaviors. Despite many studies regarding $\mathrm{OCB}$ antecedents have been reported in the literature, OCB is constantly being conceptualized by using social exchange framework to demonstrate individuals' citizenship behaviors in reaction to fair treatment by the organization (Zellars \& Tepper, 2003). Thus, further clarification and refinement of OCB antecedents or what motivate employees to demonstrate such behaviors are needed. Furthermore, as workforces consist of people who are diverse and share different attitudes, needs, desires, values and work behaviors (D'Netto \& Sohal, 1999; Morrison, 1992), the implementation of HRDM practices could change their attitudes, behaviors and also can increase their level of OCB. According to Shen, Chanda, D'Netto and Monga (2009), HRDM practices refer to organizational effort which aim to manage human resources equally and fairly. Thus, employees' perceptions and expectations of their employer's commitment and support towards them (manifested through HRDM) might shape their feelings about the organization.

\section{Literature review}

\section{Relationship between HRDM Practices and OCB}

OCB is defined as individual behavior that reflects effort beyond normal job requirements, and generally not required and directly recognized by formal reward system (Organ, 1988). In discussing the motivational source of OCB, Organ (1988) insisted that justice perceptions are the best basis in explaining and promoting OCB. Through the lens of social exchange theory, Organ (1990) also offered an explanation why employees might perform OCB as a respond or to reciprocate to the fair treatment received from their organizations.

Recently, modern business trends of globalization and increasing in workforce diversity have encouraged organization to manage diversity (Richard \& Johnson, 2001). As argued by Kirton (2003), HRM as an organizational function play an important role in managing diversity through it proactive policy in reducing inequalities as well as to attract, develop, retain and motivate diverse workforces. As such, when organization supports equity and fairness, their employees are predicted to become more committed in their job. In similar vein, employees are reported to support their organization's diversity initiatives when they perceived fairness policies and 
procedures (Pfau \& Kay, 2002; Richard \& Johnson, 2001). In addition, Colquitt et al. (2001) also reported that perceived fairness or organizational justice strongly affect employees' attitudes (i.e. job satisfaction, turnover intentions, organizational commitment) and behaviors such as OCB.

Recent study on HRDM practices by Shen et al. (2010) on 530 Chinese workers from different industries, generally found that there is a relationship between certain HRDM practices and OCB. In predicting OCB as dependent variable, study by Shen et al. (2010) focused on four salient HRDM practices in the Chinese context, that is recruitment and selection diversity management, training and development diversity management, performance appraisal diversity management and compensation diversity management. According to them, HRDM practices are designed to utilize diversity and are free from bias in all human resource functions and also to appreciate the contributions of the minorities. According to Shen et al. (2009), these approaches will help to increase the cohesiveness level among diverse employees within the organization as HRDM practices aims at treating employees fairly and equally (Shen, et al., 2010). In contrast, current study focused on five HRDM practices to investigate whether employees' perception of organization's HRDM practices affects their attitudes and their citizenship behaviors (OCBI and $\mathrm{OCBO}$ ). Current study was correlational in nature since the main objective was to identify variables that might influence two types of employees' OCB (OCBI and OCBO).

In fact, when employees perceived justice from the fair treatment they have received from the organization, they might reciprocate it by engaging more on OCB (Organ, 1988, 1990). Based on the discussion, it was expected that, as a whole, employees' perceptions on organization's HRDM practices will be positively related to OCB (OCBI and OCBO). Specifically, it was expected that each individual HRDM practices, including recruitment and selection diversity management, training and development diversity management, performance appraisal diversity management, compensation diversity management and career advancement diversity management to be positively connected with $\mathrm{OCB}$ (OCBI and OCBO).

\section{Recruitment and Selection Diversity Management}

Recruitment and selection are two important activities in human resource management field. Both processes should be considered and included in the organization of human resource plan. In addition, workforces are the core organizational resources and need to be managed and should be used properly. According to Shen et al. (2010), organization must be fair in recruitment and selection process. In order to capitalize on diversity, organization needs to ensure that recruitment and selection process are free from such stereotyping and discrimination issues. As so, a positive approach to diversity might enable organization to choose and select the best talented person for the job. For example, age, gender, disability and race play no part in the recruitment and selection process. Furthermore, these initiatives will make organization seen to be as a fair, positive and progressive place to work by diverse workforces (Resources, 2012). D'Netto and Sohal (1999) clearly stated that workforce diversity benefits the organization by creating and offering an organizational environment which attracts people from diverse labor markets. They also added that organizations can be more harmonious when workforce diversity is appreciated. 


\section{Training and Development Diversity Management}

Employee training and development processes included strategies, tools, and also procedures designed to enhance the ability and capability of organizational workforces (Delery \& Doty, 1996). According to Amirtharaj, Cross and Vembar (2011), when effectively managed, these activities can contribute to the success of the organization. Further, they insist that training can be utilized to overcome organizational problems such as turnover and others departmental problems. In addition, such activities also have the impact on employees' attitudes and performances (Amirtharaj, et al., 2011). In the case of diverse workforces, training programs are then used to cope with the group differences problems and help on enhancing respect for individual differences in terms of attitudes, values and behavior (D'Netto \& Sohal, 1999). Organization is said to be effective in managing its diverse workforces after recruiting processes by retaining them through adequate training and development opportunities to its workforces (D'Netto \& Sohal, 1999). According D'Netto, Monga, Shen and Chelliah (2008). Diversity awareness training on the other hand, may enhance diverse group integration among minority and mainstream employees. Such training will help to improve the understanding of the value of diversity, social cohesion and also contribute in improving individual and organizational performance (Rynes \& Rosen, 1995).

\section{Performance Appraisal Diversity Management}

As Schuler, Dowling and Cieri (1993) pointed out, the effective performance appraisal in the area of diversity management practices must be objective not subjective, job related, fair and without special treatment to all workforces. The inclusion of multicultural representatives on appraisal committee for example, will make diversity concerned more appreciated as well as can help in creating objective and fair performance appraisal process (D'Netto \& Sohal, 1999). Additionally, the inclusion of minorities such as migrant employees in performance appraisal process may reduce perceived discrimination amongst the mainstream and non-mainstream employees (D'Netto, et al., 2008). According to D'Netto et al. (2008), failure to use good HRDM practices in appraisal process may result in a failure to develop the performance and productivity of the employees. Hence, fair and unbiased performance appraisal process can improve employee's performance (D'Netto \& Sohal, 1999).

\section{Compensation Diversity Management}

In organizational context, the term compensation is often defined as remuneration, pay, and/or reward system used to motivate employees (Milkovich \& Newman, 2008). Compensation is a crucial segment of HRM that emphasizes planning, organizing, and controlling variety of payment systems for rewarding employees who perform jobs or services. Besides, compensation also is often viewed as the various types of pay systems including monetary and non monetary rewards (Henderson, 2006). Past research suggests that pay equity may lead to effective diversity management and organizational performance (D'Netto, et al., 2008). Furthermore, the use of principle equitable pay and performance-based pay systems is important in remuneration diversity management. According to D'Netto et al. (2008), individual 
differences (i.e. ability, knowledge, and skill) should be considered when designing the compensation structure, wage determinants and also benefit schemes. As suggested by Sturman (2001), good compensation practices would benefit the hoteliers in attracting and retaining their best employees since the hospitality industry heavily relies on their employees in delivering quality services.

\section{Career Advancement Diversity Management Practices}

Career advancement refers to organizational mechanisms used to assist organizational members to achieve their career goals (Delery \& Doty, 1996). Career advancement management can be defined as the design and implementation of organizational processes which enable the careers to be planned and managed in a way that optimizes both the needs of the organization and the preferences and capabilities of individual (Burke, Divinagracia, \& Mamo, 1998).

Within organization, the inclusion of fairness and equal employment opportunities in managing it diverse workforces are also very important. According to Ruggless (2003), organization should recognize the talents of minority employees and develop career advancement opportunities to those qualified non mainstream employees. As such, negative stereotypes assumption on minority employees should be overcome. As suggested by Fernandez (2006), positive efforts need to be done by organization in order to attract more diverse workforces talents including minority employees and also viewed as a practical career preference.

Generally, workforce diversity increases the possibility of discrimination issue among employees. According to Richard and Kirby (1999), human resource practices regarding career advancement must reflect diversity issues in order to overcome negative perceptions from diverse employees. Thus, such failure in providing a career development plan for diverse employees would negatively affect their motivation, morale, creativity, innovation and performance (Loveman \& Gabarro, 1991; Morrison, 1992; Ragins \& Scandura, 1994).

\section{Conceptual Framework}

Based on the preceding discussion, a conceptual framework is proposed as depicted in Figure1. To conceptualize the relationship between HRDM practices and OCB (OCBI and OCBO), Social Exchange Theory (Blau, 1964) will be used. It is reasonable to assume that employees might have the tendency to become more committed when they believe that their organization supports equity and fairness. Subsequently, employees reciprocate their perceptions accordingly through positive attitudes and behaviors to the organization, which in turn enhance their willingness to engage in high level of OCB. 


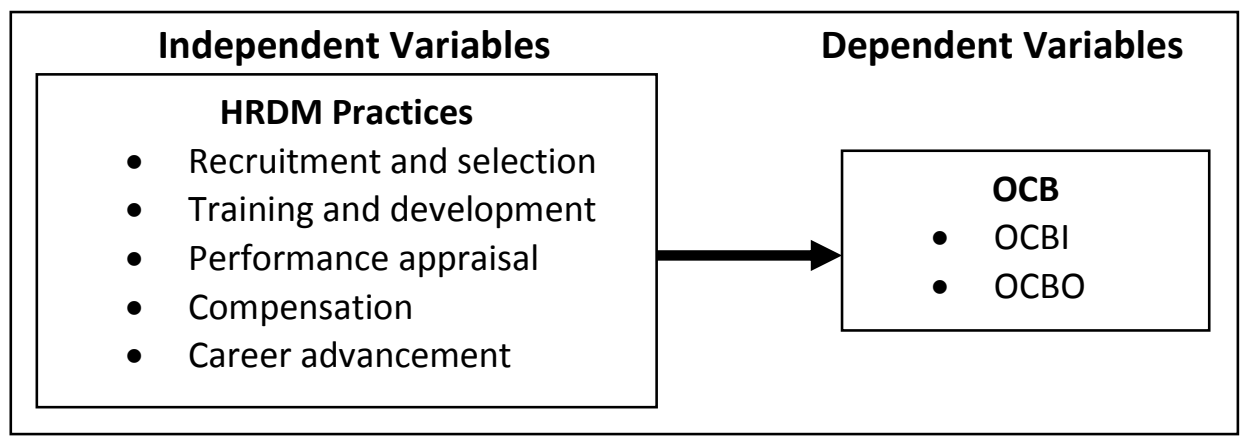

Figure 1: Proposed conceptual framework

\section{Prepositions}

Based on the above literature review, the following prepositions will be addressed such as: $P 1$ : Employees' perceptions of organization's HRDM practices will have a positive relationship on OCBI.

P2: Employees' perceptions of organization's HRDM practices will have a positive relationship on OCBO.

\section{Conclusion}

Empirical evidence shows that OCB is a significant contributor to the growth and survival of the organization. Although many studies about OCB antecedents and their classifications along individual, task and organizational characteristics as well as leadership behaviors have been reported in the literature (Organ, et al., 2006), further refinement and classification of OCB antecedents aimed at logical arrangement and reporting of the OCB antecedents may be important to OCB researchers and practitioners (Spitzmuller, Van Dyne, \& Ilies, 2008). In addition, understanding the OCB antecedents among diversified workforces is essential to value their attitudes towards work environments and in ensuring successful business.

\section{References}

Amirtharaj, S. M. D., Cross, S. K. R., \& Vembar, V. (2011). HR Concepts in Hotel Industry Towards Employee Training and Development. International Journal of Human Resource, 1, 4456.

Barnard, C. I. (1938). The Functions of the Executive. Cambridge, MA: Harvard University Press.

Bateman, T. S., \& Organ, D. W. (1983). Job satisfaction and the good soldier: The relationship between affect and employee "Citizenship". Academy of Management Journal, 26, 587595.

Blau, P. M. (1964). Exchange and power in social life. New York: John Wiley \& Sons.

Bolino, M. C., \& Turnley, W. H. (2003). Going the extra mile: Cultivating and managing employee citizenship behavior. Academy of Management Executive, 17, 60-71. 
Burke, R. J., Divinagracia, L. A., \& Mamo, E. (1998). Training and development activities and career success among Filipino managerial women. Career Development International, 3, 260-285.

Colquitt, J. A., Conlon, D. E., Wesson, M. J., Porter, C. O. L. H., \& Ng, K. Y. (2001). Justice at the millennium: A meta-analytic review of 25 years of organizational justice research. 88 , 425-445.

D'Netto, B., Monga, M., Shen, J., \& Chelliah, J. (2008). Manufacturing Employees' Perceptions of Human Resource Diversity Management Practices in Australia. Sydney, Australia: The Australian Workers' Union.

D'Netto, B., \& Sohal, A. S. (1999). Human resource practices and workforce diversity: an emperical assessment International Journal of Manpower, 20, 530-547.

Delery, J. E., \& Doty, D. H. (1996). Mode of theorizing in strategic human resource management: Tests of universalistic, contigency, and configurational performance predictions. Academy of Management Journal, 39, 802-835.

Fernandez, G. (2006). Proactive approach needed to attract minority workers. Nation's Restaurant News, 40, 18.

Henderson, R. I. (2006). Compensation Management in a Knowledge - Based World (10 ed.). Upper Saddle River, NJ: Pearson-Prentice Hall.

Katz, D. (1964). The motivational basis of organizational behavior. Behavioral Science, 9, 131146.

Katz, D., \& Kahn, R. L. (1978). The social psychology of organizations (2nd ed.). New York: Wiley.

Loveman, G. W., \& Gabarro, J. J. (1991). The managerial implications of changing workforce demographics: A scoping study. Human Resource Management, 30, 7-29.

Milkovich, G. T., \& Newman, J. M. (2008). Compensation. Boston: Irwin McGraw-Hill.

Morrison, A. M. (1992). Leaders: Strategies for Leadership Diversity. San Francisco: Bass Publishers

Niehoff, B. P., \& Moorman, R. H. (1993). Justice as a mediator of the relationship between methods of monitoring and organizational citizenship behavior. Academy of Management Journal, 36, 527-556.

Organ, D. W. (1988). Organizational citizenship behavior: The Good Soldier Syndrome. MA: Lexington Books.

Organ, D. W. (1990). The motivational basis of organizational citizenship behavior. Research in Organizational Behavior, 12, 43-72.

Organ, D. W., Podsakoff, P. M., \& MacKenzie, S. B. (2006). Organizational Citizenship Behavior: Its Nature, Antecedents, and Consequences Tousand Oaks, California: Sage Publications.

Organ, D. W., \& Ryan, K. (1995). A meta-analytic review of attitudinal and dispositional predictors of organizational citizenship behavior. Personnel Psychology, 48, 775-802.

Pfau, B. N., \& Kay, I. T. (2002). The human capital edge: 21 people management practices your company must implement (or avoid) to maximize shareholder value. Hightstown, NJ: McGraw-Hill.

Podsakoff, P. M., MacKenzie, S. B., Paine, J. B., \& Bachrach, D. G. (2000). Organizational Citizenship Behaviors: a critical review of the theoretical and empirical literature and suggestions for future research. Journal of Management, 26, 513-563. 
Ragins, B. R., \& Scandura, T. A. (1994). Gender differences in expected outcomes of mentoring relationships. Academy of Management Journal, 37, 957-971.

Resources, H. (2012). Equality and diversity in recruitment and selection Retrieved May 3, 2012, from http://www.bristol.ac.uk/hr/resourcing/additionalguidance/equality/

Richard, O. C., \& Johnson, N. B. (2001). Understanding the impact of human resource diversity practices on firm performance. Journal of Managerial Issues, 13, 177-195.

Richard, O. C., \& Kirby, S. L. (1999). Organizational justice and the justification of work force diversity programs. Journal of Business and Psychology, 14, 109-118.

Ruggless, R. (2003). Operators outline programs, initiatives to guarantee diversity among workforce. Nation's Restaurant News, 37, 43.

Rynes, S., \& Rosen, B. (1995). A field survey of factors affecting the adoption and perceived success of diversity training. Personnel Psychology, 48, 247-270.

Schuler, R. S., Dowling, P. J., \& Cieri, H. D. (1993). An integrative framework of strategic international human resource management. International Journal of Human Resource Management, 5, 717-764.

Shen, J., Chanda, A., D'Netto, B., \& Monga, M. (2009). Managing diversity through human resource management: an international perspective and conceptual framework. The International Journal of Human Resource Management, 20, 235-251.

Shen, J., D'Netto, B., \& Tang, J. (2010). Effetcs of human resource diversity management on organizational citizen behaviour in the Chinese context. The International Journal of Human Resource Management, 21, 2156-2172.

Smith, C. A., Organ, D. W., \& Near, J. P. (1983). Organizational citizenship behavior: Its nature and antecedents. Journal of Applied Psychology, 68, 653-663.

Spitzmuller, M., Van Dyne, L., \& Ilies, R. (2008). Organizational citizenship behavior. A critical review and extension of its nomological network. In C. Cooper \& J. Barling (Eds.), Handbook of organizational behavior. New York: Sage.

Sturman, M. C. (2001). The compensation conundrum: Does the hospitality industry shortchange its employees--and itself? . The Cornell Hotel \& Restaurant Administration Quarterly, 47, 70-76.

Triana, M. d. C., Kim, K., \& Garcia, M. F. (2011). To help or not to help? Personal value for diversity moderates the relationship between discrimination against minorities and citizenship behavior toward minorities. Journal of Business Ethics, 102, 333-342.

Zellars, K. L., \& Tepper, B. J. (2003). Beyond social exchange: New directions for organizational citizenship behavior theory and research. Research in Personnel and Human Resources Management, 22, 395-424. 